NBER WORKING PAPER SERIES

\title{
LOVE OR MONEY? HEALTH INSURANCE AND RETIREMENT AMONG MARRIED COUPLES
}

\author{
Kanika Kapur \\ Jeannette Rogowski \\ Working Paper 12273 \\ http://www.nber.org/papers/w12273
}
NATIONAL BUREAU OF ECONOMIC RESEARCH 1050 Massachusetts Avenue
Cambridge, MA 02138
May 2006

The authors are grateful to Paul Devereux, Alan Gustman, Lynn Karoly, Nicole Maestas, Constantijn Panis and Susann Rohwedder for helpful comments. Sandy Chien provided invaluable programming support. The authors would like to acknowledge support from Patricia Willis at the Department of Labor, and funding under contract number J-9-P-7-0045 from the Employee Benefits Security Administration at the Department of Labor. The views expressed herein are those of the author(s) and do not necessarily reflect the views of the National Bureau of Economic Research. The views expressed herein are those of the author(s) and do not necessarily reflect the views of the National Bureau of Economic Research.

(C2006 by Kanika Kapur and Jeannette Rogowski. All rights reserved. Short sections of text, not to exceed two paragraphs, may be quoted without explicit permission provided that full credit, including @ notice, is given to the source. 
Love or Money? Health Insurance and Retirement Among Married Couples

Kanika Kapur and Jeannette Rogowski

NBER Working Paper No. 12273

May 2006

JEL No. I1, J32

\begin{abstract}
Kanika Kapur
School of Economics

University College

Dublin

IRELAND

kanika.kapur@ucd.ie

Jeannette Rogowski

Department of Health Systems and Policy

UMDNJ-School of Public Health

335 George Street, Suite 2200

New Brunswick, NJ 08903

and NBER

rogowsje@umdnj.edu
\end{abstract}

ABSTRACT

This paper examines the role of employer provided health insurance in the retirement decisions of dual working couples. The near elderly have high-expected medical expenditures; therefore, availability of health insurance is an important factor in their retirement decisions. We determine if access to retiree health insurance for early retirement enables couples to time their retirement together - a behavior called "joint retirement." We find that wives' retiree health insurance more than doubles the propensity to retire jointly, suggesting that health insurance is an important consideration in coordinating retirement decisions among couples. Even though retiree health insurance has a substantial effect on joint retirement, its effect on overall employment patterns is modest, accounting for a 2 percentage point fall in employment. 


\section{Introduction}

The majority of families facing retirement in the United States today include two workers. ${ }^{1}$ With the baby-boom generation fast approaching retirement, the proportion of twoworker couples coordinating retirement choices will increase. Given these trends, an understanding of how married couples choose to time their retirements from the labor force will be critical to forecasting how the near elderly workforce in the United States will evolve in the coming years. While the early literature on retirement focused primarily on men, several recent studies have examined the retirement behavior of dual working couples. This research has demonstrated that couples tend to time their retirement together, possibly because they value joint leisure after retirement.

The availability of health insurance is a crucial factor in a couple's ability to retire jointly. The near elderly are a vulnerable segment of the population. Because the prevalence of poor health and chronic disease rises with age, the near elderly have higher expected medical expenses than younger cohorts. For instance, average annual health care expenditures for persons age 45-64 are 85\% higher than for persons aged 18-44 ( $\$ 3,500$ compared to $\$ 1,900$ ) (AHRQ, 2003). As a result, being uninsured may threaten their economic security. However, the near elderly can have problems gaining access to affordable health insurance. Few routes to public insurance exist: Unless blind or disabled, persons under age 65 cannot qualify for Medicare or Medicaid. Options for purchasing health insurance in the private-individual markets are often equally restrictive, largely because of high premium costs. Workers who leave an insured job have the option to continue group coverage- known as COBRA coverage--for up to 18 months by paying 102 percent of the premium. ${ }^{2}$ Only a small fraction of those eligible to

1 Authors' calculations based on the Health and Retirement Survey data.

2 From the law that established the program, the Consolidated Omnibus Budget Reconciliation Act of 1985. 
purchase COBRA coverage do so, however. ${ }^{3}$ The high cost of COBRA coverage $(\$ 7,000$ to $\$ 8,000$ for family coverage) may be a deterrent for many, especially for those who have just left a job (Scandlen, 2001). ${ }^{4}$ Thus, prior to the age of Medicare eligibility (65), employment-based sources for their health insurance remain a valuable resource for the near elderly. In fact, among persons aged 54-64 in 2002, 73 percent were covered by employment-based sources of health insurance. Employers are a particularly important source of insurance for early retirees (those retiring before the age of Medicare eligibility). While 38 percent of all retirees over age 65 were covered by employment-based insurance in 2002, 64 percent of early retirees (55-64) had such coverage. Despite the importance of retiree health insurance, employer coverage for retirees has been declining over time. While 68 percent of retirees were covered by employer provided health insurance in 1992, only 45 percent of retirees had such coverage in 2002. Furthermore, 45 percent of workers were offered retiree health insurance coverage in 1992 compared with 30 percent in $2002 .^{5}$

In this paper, we examine the role of employer provided health insurance in the retirement decisions of dual working couples. In particular, we determine if access to retiree health insurance for early retirement enables couples to time their retirement together - a behavior that we call "joint retirement." We also analyze whether the influence of health insurance on joint retirement decisions depends on the health of the couple. Access to retiree health insurance for early retirees through either husband's or wife's employer should increase

\footnotetext{
3 Estimates of the take-up rate among eligible workers are about 20 to 25 percent (Flynn, 1994; Berger et al., 1999). 4 Gruber and Madrian (1995) found that continuation coverage increased retirement; however, we are unable to estimate the effect of continuation coverage on joint retirement since all variation in these laws occurred before the first wave of the Health and Retirement Study.

5 Authors' calculations based on the Health and Retirement Study. The definition of employer provided retiree coverage changed between 1992 and 2002. In 1992, retiree health insurance was measured by a question that asked if the employer provided coverage to retirees. In 2002, the question was targeted at retirement before the age of 65 . Virtually all employers who offer retiree coverage make such coverage available to retirees who are pre-65 and over 65 (Kaiser/Hewitt, 2002); therefore, we do not believe that this change in survey question should matter.
} 
the propensity to retire jointly. To illustrate, for a typical near-elderly couple where the husband is two years older than the wife, the husband is eligible for Medicare two years earlier than his wife. If either spouse has health insurance that can cover the wife after retirement, the wife will be able to retire with her husband when he is sixty-five and maintain health insurance coverage. On the other hand, if the wife has employer provided health insurance, but no access to postretirement health insurance, the wife will need to postpone retirement until she reaches sixtyfive, reducing the couple's ability to jointly retire. This is a form of "job lock." We examine the effect of health insurance on joint retirement using data from the Health and Retirement Study (HRS). The HRS is particularly well suited to our study, since it contains detailed longitudinal information on labor force participation, retirement, health and health insurance for near elderly and elderly couples.

\section{Literature Review}

A growing literature has begun to examine retirement for dual working couples. The early literature in this area used data from the 1970s and 1980s and demonstrated that husbands and wives tend to retire at the same time (Hurd 1990, Blau 1998, Gustman and Steinmeier 2000, An, Christensen and Gupta, 1999). For instance, Hurd (1990) used data from the 1982 New Beneficiary Survey (NBS) to study the timing of retirement among married couples. This was a survey of individuals who received Social Security benefits in a one-year window beginning in June 1980. The study found that $25 \%$ of married men and $28 \%$ of married women retired within one year of each other. Similar evidence of joint retirement among couples was found by Blau (1998), using data from the Retirement History Survey in the 1970s and by Gustman and 
Steinmeier (2000) using the National Longitudinal Survey of Mature Women in the last year of the survey, $1989 .^{6}$

These studies found complementarity of leisure to be the most likely explanation for joint retirement. Very little of the coordination in retirement could be attributed to economic variables or to assortative mating. However, these early studies may be problematic, since they often lacked detailed information on pensions and Social Security.

More recent work has improved on this earlier research by using detailed information on pensions and Social Security available in the HRS. As with the earlier literature, these studies continue to find that couples tend to retire together (Maestas, 2001; Johnson and Favreault, 2001). Both Gustman and Steinmeier (2002) and Maestas (2001) develop structural models of joint retirement behavior that find that complementarity of leisure is an important determinant of joint retirement. In an alternative approach to analyzing joint retirement, Coile (2003) estimates reduced form models of husband's and wife's retirement as a function of own and spousal financial incentives. Men and women are found to respond similarly to their own incentives; men also respond to their wives' incentives, but not vice versa. While most studies find that poor health is associated with retirement, the effect of spousal health on retirement is more mixed. ${ }^{7}$ Johnson and Favreault (2001) employ a reduced form approach to examine the effect of spousal employment status and health on retirement. They find that men and women are more likely to retire if their spouse has left the labor market; however, they are less likely to retire if the spouse appeared to have left the labor force because of poor health. Related research has found mixed evidence of a direct effect of spousal health on retirement. While several studies demonstrate that poor spousal health is associated with continued work (O’Rand, Henretta, and Krecker, 1992,

6 The sociological literature on joint retirement has focused on the role of gender attitudes, norms, and family trajectories (Henretta, O'Rand, and Chan, 1993a, 1993b).

7 Currie and Madrian (1999) provide a review of the literature on health and retirement. 
Hurd, 1990, Pienta, 1997), others have not found a significant link (Campione, 1987, Maury, 2001).

There is limited research on the importance of post-retirement health benefits in joint retirement decisions for couples. Madrian and Beaulieu (1998) provide suggestive evidence that health insurance may play a role in joint retirement of married couples. They find that married men are more likely to retire when their wives reach 65 - the age of Medicare eligibility. However, their analysis uses the 1980 and 1990 Census data that does not include information on health insurance or pensions. A recent study by Blau and Gilleskie (2003) develops a structural model of work, retirement, and health utilization that accounts for the role of health benefits. This study finds small effects of retiree health insurance. However, a large body of literature has demonstrated that retiree health insurance facilitates early retirement among men (Karoly and Rogowski 1994, Madrian, 1994, Gruber and Madrian, 1995, Hurd and McGarry, 1996, Headen, Clark, and Ghent, 1997, Rust and Phelan, 1997, Johnson, Davidoff, and Perese, 1999, Rogowski and Karoly, 2000, Blau and Gilleskie, 2001, 2003). ${ }^{8}$ A few studies have also demonstrated that retiree health benefits play a role in retirement decisions for women (Quinn 1997, Rogowski and Karoly, 2001). Therefore, further exploration into the role of retiree health insurance in the joint retirement of couples is merited. The advantage of the reduced form approach compared to a structural approach is in the transparency and simplicity of the modeling assumptions. ${ }^{9}$ We use a reduced form approach that directly examines the effect of health insurance on joint retirement. Understanding joint retirement behavior is important in order to obtain accurate projections of

8 Contrary to most of the literature, French and Jones (2003) find relatively small effects of health insurance on retirement. Their estimates compare the retirement behavior of the wealthy to the less wealthy under the assumption that the wealthy are more likely to be able to self insure.

${ }^{9}$ Gruber and Madrian (2004) raise several concerns with Blau and Gilleskie's study. First, the sample is relatively small and had a much lower rate of health insurance coverage than a representative sample of HRS respondents, potentially leading to a downward biased estimate of health insurance. Second, the study sample is young for a study on retirement. Third, predictions from the structural model are quantitatively quite different from the data in several cases raising concern about the appropriateness of the assumptions in the structural model. 
labor force participation in the future. Furthermore, increased health insurance availability may increase the welfare of the near-elderly by making joint retirement more feasible.

\section{Conceptual Framework}

We follow the conceptual framework laid out in the literature on joint retirement (Blau and Gilleskie, 2003; Maestas 2001) by postulating that a couple's utility depends on each member's choice of employment and other factors such as health and consumption. Couples may derive value from retiring together because of complementarities in leisure that enter the couples' utility function. The availability of health insurance reduces couples' exposure to the financial risk of high medical expenditures. However, health insurance availability depends on employment choice. Therefore, couples must choose whether each spouse will retire based on health insurance availability after retirement. The availability of retiree health insurance (whether or not the employer offers a health insurance plan to retirees) may also have a direct effect on an individual's ideal retirement date, independent of his spouse's retirement plans. However, the focus of this paper is on the behavior of joint retirement rather than the timing of individual retirement. $^{10}$

Access to retiree health insurance reduces or eliminates couples' exposure to high medical expenses if they choose to retire. For couples who are both under the age of 65 , retiree health insurance would increase joint retirement since these couples could retire and maintain health insurance coverage until both members become eligible for Medicare at age 65. If, on the other hand, the couple had access to employer provided health insurance, but no retiree health insurance, at least one spouse with the employer provided health insurance plan would need to

\footnotetext{
${ }^{10}$ Descriptive statistics (that do not account for the censoring of retirement age) show that when a couple has access to retiree health insurance from the husband, both husband and wife are about one year younger at retirement compared to those couples where husbands do not have employer provided health insurance; however, there are no differences by wife's retiree health insurance status.
} 
continue to work until the couple was over 65 to maintain health insurance benefits. Similarly, for couples with one member over the age of 65 and another member under the age of 65 , retiree health insurance would enable the younger member to retire jointly with the older member and maintain health insurance coverage. For couples who are both over the age of 65 and hence eligible for Medicare, retiree health insurance is likely to play a smaller role. Even so, retiree health insurance can provide prescription drug coverage and other supplementary benefits that are valuable for an older population. Therefore, couples who lack retiree health insurance benefits but have employer provided health insurance may delay retirement for at least one member to ensure continued access to these supplemental benefits.

\section{Data}

Our analysis uses the HRS, a nationally representative panel survey of individuals born from 1931 to 1941 in the first wave of the survey. Following the first wave of data collection in 1992, subsequent waves of data have been collected every two years. We use the first six waves of the HRS (1992-2002). In addition to basic demographic and health data, the HRS collects detailed longitudinal information about labor force status, health insurance, retiree health benefits, income, and wealth. The HRS data have also been linked to Social Security earnings histories and to employer pension plan data for the majority of the sample. Data are collected for sampled individuals and their spouses.

The HRS surveyed 4846 married couples in 1992. We restrict our analysis sample to couples where both members of the couple were working full-time in 1992. We drop couples that had missing data for our key analysis variables - health insurance and labor force participation. 
These restrictions reduce our sample size to 1497 couples. ${ }^{11}$ Most of this reduction in sample size stems from the restriction to dual working couples. The analysis data set is structured as couple-year observations. A couple can have a maximum of five observations. The first observation captures retirement between 1992 and 1994; the second observation captures retirement between 1994 and 1996; the third observation captures retirement between 1996 and 1998; the fourth observation captures retirement between 1998 and 2000; and the fifth observation captures retirement between 2000 and 2002. The data are restricted to observations where both members of the couple are working at the baseline year. ${ }^{12}$ Therefore, once one member of the couple retires, the couple exits the data set.

We measure retirement as a transition in the labor force status from full time work at the baseline year to self-reported part or full retirement at the next survey date. ${ }^{13}$ We classify health insurance for couples using the following mutually exclusive variables defined separately for the husband and the wife: (a) holds own employer provided health insurance, but no retiree health insurance, (b) holds own employer provided health insurance and retiree health insurance, and (c) does not hold own employer provided health insurance. In 1992 and 1994, HRS measured retiree health insurance using a question that asks if the employer provided plan reported by the surveyed individual covers retirees. In 1996, HRS changed the wording of the question to ask if the surveyed individual could continue coverage to 65 if they left their job now. Ninety-one

\footnotetext{
${ }^{11}$ We need to restrict the sample to dual-working couples in order to study joint retirement behavior. However, this restriction may compromise the generalizability of our results if the profile of dual-working couples changes over time.

12 We do not model reentry into the labor force after partial or full retirement. We model only the first observed transition to retirement for a couple. Twelve percent of the couples have multiple observed transitions to retirement. 13 Since employer provided health insurance is usually offered to full-time workers and not to part-time workers, we believe the appropriate definition of retirement for the purposes of studying health insurance is the transition from full time work to part or full retirement. However, we have checked the sensitivity of our results to the definition of retirement. We reestimated our model with an alternative definition of retirement that allow for transitions from full time or part time work to full retirement and find somewhat smaller effects of health insurance; however, this effect remains statistically significant.
} 
percent of employers that offer retiree health benefits provide coverage for both pre- 65 and age $65+$ retirees; therefore it is unlikely that this change in the HRS will have much impact on our results (Kaiser/Hewitt, 2002). While the measure of retiree health insurance in the HRS in 1992 and 1994 identifies if the employer offers retiree health insurance to any employees, it does not determine if the surveyed employee is eligible for these benefits. In our analysis, we include year indicators to absorb the effect of changes in the survey instrument over time. We have also estimated secondary models that include an interaction between an indicator variable for survey years from 1996 on with retiree health insurance to determine if the effect of retiree health insurance varies due to the change in survey instruments. The interaction was small and statistically insignificant suggesting that our results are not sensitive to the change in survey instrument.

HRS data from 1996 on also separately identifies health insurance obtained from a current employer versus health insurance obtained from a former employer or union. We construct a secondary set of health insurance measures that pertain to the current employer only.

We use linked, restricted access data from the Social Security administration based on the Social Security Earnings and Benefits File to construct measures of social security wealth. Not all surveyed individuals gave permission to retrieve and link their social security information to their HRS records. Linked data are available for 88 percent of our sample. In cases where linked data were not available, we used measures of social security wealth imputed as part of the RAND HRS-SSA project (StClair et al., 2002). The social security variables included in the RAND HRS-SSA data are household social security wealth in 1992, projected household social security wealth at age 62 , and projected household social security wealth at age 65 . We used these variables to construct measures of household social security wealth at the baseline year and 
the gain in social security wealth obtained by delaying retirement past the follow-up survey year. For couples who were under the age of 62 , we assumed that baseline social security wealth was equal to the wealth in 1992. For couples who were between the ages of 62 and 65 , we assumed that baseline social security wealth was equal to wealth at 62 , and for couples who were over the age of 65 , we assumed that baseline social security wealth was equal to wealth at 65 . The gain in social security wealth was calculated as the difference between baseline wealth and projected wealth at 65 . All wealth measures are adjusted for inflation.

We construct pension measures using self reported pension data and employer reports of pension benefits. Ongoing validation research suggests that self reported pension data are preferable to employer information for defined contribution (DC) plans. However, employer reports are likely to be a better measure of pension wealth for defined benefit (DB) plans. ${ }^{14}$ Therefore, we use self reported DC pension balances as our measure of DC pension wealth. ${ }^{15} \mathrm{We}$ use linked data from an employer survey of HRS respondents to construct measures of DB pension wealth. ${ }^{16}$ These variables were derived from the 1992 HRS Pension Plan Detail Data Set for individuals who in 1990 provided the names and addresses of their employers. Summary pension plan descriptions were obtained from employers and coded to create measures of pension wealth. Employer provided pension data are non-missing for both members of a couple for 41 percent of our sample. ${ }^{17}$ The employer-reported pension variables included in the RAND HRS-SSA data are employer pension wealth in 1992 from current and past jobs, projected pension wealth at age 62 , and projected pension wealth at age 65 . We used these variables to

14 Personal communication with Susann Rohwedder. 15 We use data provided by Gustman and Tabatabai (2003) that include imputations for missing pension balances. We have checked the sensitivity of our results to the inclusion of imputed data by estimating the pension coefficients using the subset of observed data only, and we find that our results for health insurance are not sensitive to the use of imputed pension data.

16 We thank Stan Panis for providing us with pension measures from the pension calculator.

${ }^{17}$ We reestimated the model on the sub-sample with non-missing DB pension balances and found a similar pattern of results; however, these results were less precise due to the lower sample size. 
construct measures of pension wealth at the baseline year and the gain in pension wealth obtained by delaying retirement past the follow-up survey year using a method similar to the construction of social security wealth. Since DB pension wealth information is only available in 1992, this variable is potentially mismeasured for individuals who change jobs. In supplementary analyses, we have checked the sensitivity of our results to this measurement issue by estimating the DB pension wealth coefficients on the subsample who do not change jobs and by including an indicator for job change in our model. We find very similar results for the health insurance effects. We do not choose this variable specification for our main results because of the potential endogeneity of job change. We also include indicators for type of pension plan - DB plan, DC plan, or no plan that are constructed using self reports of pension benefits.

Table 1 contains weighted means for the analysis sample. The sample consists of 3370 couple-year observations. Neither member of the couple is observed retiring in 73 percent of the observations. We define a couple to have jointly retired when both members of the couple retire in the time between two consecutive interviews. Joint retirement is observed in 6 percent of couple-year observations. Husbands are more likely to retire first than wives, most likely because they are older than their wives, on average four years. While the table reports means for coupleyear observations, which is the level of the analysis, it is also useful to examine the means for couple observations. We find that 12.3 percent of couples retire jointly, 27.4 percent of couples have the husband retiring first, and 16.2 percent of couples have the wife retiring first (not reported in tables).

Table 1 also shows that about half of husbands have retiree health insurance from their own jobs whereas only about one quarter of wives have retiree health insurance. Husbands' pension wealth is substantially higher than wives' pension wealth for both DB and DC plans. 
Husbands are also more likely to have a pension plan than their wives, and this difference is larger for DB plans than for DC plans. Husbands also have wages that are, on average, $\$ 5$ per hour higher than their wives, and have almost six additional years of job tenure. Women may have interrupted careers during their childbearing years leading to shorter tenure than their husbands at the brink of retirement. In addition, women are on average four years younger than their husbands. Both these factors may lead to women being "behind" their husbands in the accrual of retirement benefits and therefore, may impact their decision to retire jointly with their husbands. .

\section{Empirical Model}

Our analysis focuses on the role of health insurance in enabling couples to retire jointly. We parameterize a couple's retirement outcome in each time period as a multinomial variable with the following outcomes: (a) joint retirement where both husband and wife retire between the baseline year and follow-up year, (b) husband retires but wife does not retire (c) wife retires but husband does not retire, and (d) neither husband nor wife retires.

Table 2 shows the descriptive relationship between health insurance and retirement outcomes. We hypothesize that couples with retiree health insurance should be more likely to retire jointly than couples with employer provided health insurance, but no retiree health insurance. Couples with no employer provided health insurance are free to time their retirement independent of health insurance considerations; however these couples may face tighter budget constraints that affect the timing of retirement. The simple tabulation in table 2 shows that husbands with retiree health insurance do not appear to retire jointly more frequently than husbands with employer provided health insurance with no retiree health insurance $(\mathrm{p}=0.69)$. However, husbands with retiree health insurance are about 4 percentage points more likely to 
retire before their wives than to continue working $(\mathrm{p}=0.004)$. Wives with retiree health insurance are about 3 percentage points more likely to retire jointly with their husbands compared to wives who have employer provided health insurance, but lack retiree health insurance $(p=0.02)$. Wives with retiree health insurance are no more likely to retire before their husbands $(\mathrm{p}=0.45)$ or to retire after their husbands $(\mathrm{p}=0.35)$. These descriptive patterns suggest that wives' retiree health insurance has a stronger effect on joint retirement than the husbands' retiree health insurance. However, multivariate analyses are necessary to determine if these descriptive patterns are robust to control variables.

We estimate a discrete time multinomial logit model of retirement. There are several advantages of the discrete time approach. This approach enables us to use data from couples who do not retire during the year. We are also able to update health insurance information and other explanatory variables to the appropriate year, rather than relying on baseline characteristics measured in first year of the survey. Furthermore, our measurement of retirement between survey dates implies that the analysis is less affected by seam bias in retirement reporting or errors in the retirement dates.

We assume that retirement behavior is determined by the following model:

$$
\operatorname{Pr}\left(R_{f t}=j\right)=f\left(\alpha+\beta_{1} H I_{h f t}+\beta_{2} H I_{w f t}+\beta_{3} X_{h f t}+\beta_{4} X_{w f t}+\beta_{5} Z_{f t}\right)
$$

In this model, retirement outcomes are denoted by $\mathrm{R}_{\mathrm{ft}}$, where $\mathrm{f}$ denotes the family and $\mathrm{t}$ denotes the time period. $\mathrm{R}_{\mathrm{ft}}$ may take any of four values -- joint retirement, husband retires first, wife retires first, or neither spouse retires. The key variables of interest are husband's and wife's employer provided health insurance, denoted by the vector $\mathrm{HI}_{\mathrm{hft}}$ for husband's health insurance and $\mathrm{HI}_{\mathrm{wft}}$ for wife's health insurance. $\mathrm{HI}_{\mathrm{hft}}$ includes an indicator for the husband having retiree health insurance offered through his own employer and an indicator for the husband having no 
employer provided health insurance through his own employer. The omitted category is the husband having employer provided health insurance, but no retiree health insurance from his own employer. $\mathrm{HI}_{\mathrm{wft}}$ for wife's employer provided health insurance is defined analogously.

Our analysis assumes that health insurance is exogenously determined from the employment decision. In other words, individuals do not choose health insurance based on their expected retirement choices. There are several reasons that we believe that this assumption is valid. First, employees must typically satisfy tenure requirements before qualifying for retiree health benefits. The KFF-HRET (2005) employer survey found that 89 percent of employers had age and tenure requirements for retiree health benefit eligibility. The most frequent tenure requirement was 10 years of service (49 percent), followed by 15 years of service (14 percent). In our data, individuals choose jobs well before their retirement decisions (average job tenure is 19 years for male retirees and 13 years for female retirees). Therefore, it is usually impossible for individuals to change jobs close to their retirement dates in order to obtain retiree health benefits, since in most jobs, they would not be eligible for benefits. Second, there is evidence that individuals are often not well informed about the details of their employer benefit packages. For example, research has shown only about half of HRS respondents can correctly identify their retiree benefits, further suggesting that individuals are not as forward looking as we may believe (Gustman and Steinmeier, 2001). Third, since the early 1990s, employers have been scaling back on the offer of retiree health insurance and on the generosity of benefits for retirees (KFF-HRET, 2005). Many employers who continued to provide these benefits began reserving the right to alter the retiree health insurance offer so that these benefits became less certain for active workers. Individuals who wanted to shop for retiree benefits would have no guarantee that the plan would be around when they decided to retire. Fourth, we examine job transitions in our data 
to document the frequency of transitions into jobs that provide retiree health insurance. If there are few transitions into jobs that offer health insurance, presumably that can be interpreted as evidence that the endogeneity of retiree health insurance is not a pressing concern. Our data showed that only 2.2 percent of men and 1.9 percent of women switched from jobs that did not offer retiree health benefits to jobs that offered these benefits. Thus, the empirical evidence suggests that there are very few job transitions that are consistent with the notion of shopping for retiree health benefits. Therefore, like most of the existing literature (see for example Blau and Gilleskie (2003)), we assume that health insurance choice is exogenously determined.

The control variables in the model include a full set of demographic controls for husband and wife characteristics $\left(\mathrm{X}_{\mathrm{hft}}\right.$ and $\left.\mathrm{X}_{\mathrm{wft}}\right)$. These include categories for the husband's age and the wife's age. Since the gap between the husband's and wife's age is likely to be important in determining joint retirement, we have also included interactions between husband and wife age categories. Other control variables include husband and wife education (less than high school, high school, or college) and husband and wife health parameterized using self reports of fair or poor health. Poor health is likely to reduce productivity in the work force and the ability to work, and therefore to increase the propensity to retire. Couples where one member has poor health may be more likely to retire jointly if care giving is important. On the other hand, medical care for a health condition is costly; therefore individuals may have an incentive to keep working to pay for health care. We would expect health insurance to play a role in determining whether couples with adverse health can retire jointly. We test this hypothesis by including interactions of health insurance and health in the model. We have also included control variables for the husband's and wife's job characteristics. These include wages, pension benefits, and job tenure. Since the opportunity cost of retirement is higher for high wage workers, we would expect high 
wage workers to be less likely to retire. ${ }^{18}$ On the other hand, DC employer provided pension benefits should increase workers' ability to retire by providing resources for retirement. The effect of DB benefits on retirement depends on the expected gain from waiting to retire - a higher expected gain should reduce retirement in the current time period. When pension wealth data are missing, we include an indicator for missing data in the model and estimate the model on the full sample. ${ }^{19}$ The vector $\mathrm{Z}_{\mathrm{ft}}$ includes family level variables such as race, social security wealth, household wealth, length of time between interviews, and year indicators. All models are weighted by household weights provided in the HRS and standard errors are adjusted for multiple observations per household. ${ }^{20}$

\section{Results}

The results from the multinomial logit models of retirement are reported in table $3 .{ }^{21} \mathrm{We}$ report relative risk ratios (RRR) for the outcomes - husband retires first, wife retires first, and neither retires, relative to the baseline outcome of joint retirement. The relevant test of significance compares the RRR to 1 - an RRR of 1 implies that the variable has no effect.

\section{Effect of Health Insurance on Joint Retirement}

We find that husbands' health insurance has a statistically insignificant effect on retirement outcomes in table 3 . However, the presence of a wife's retiree health insurance significantly increases the probability of joint retirement relative to the husband retiring first.

18 It can be argued that wages are endogenous to the retirement choice. We reestimate the models in the paper without controls for wages and find very similar results for the health insurance variables of interest. We also estimated alternative versions of the models with a fuller detailed set of job controls that included industry indicators, occupation indicators, and tenure. We found similar results for the health insurance variables with these additional controls.

19 If we restrict the sample to observations where we have non-missing pension data, we find imprecise estimates of health insurance. This loss of precision is solely due to the change in the sample rather than the inclusion of pension controls since we continue to find imprecise health insurance effects in the restricted sample even without the inclusion of pension controls in the model.

20 Unweighted results are very similar to the weighted results reported in the paper.

21 Using a Hausman test, we confirmed that the Independence of Irrelevant Alternatives assumption of the multinomial logit model is not violated in these models. 
Couples where wives have retiree health insurance are also significantly more likely to retire jointly rather than to postpone retirement. Predicted probabilities based on model estimates show that the propensity to retire jointly increases by 3.4 percentage points, from 4.1 percent if all wives had employer provided health insurance, but no retiree health insurance to 7.5 percent if they had retiree health insurance, almost doubling the effect of health insurance. The predicted probability of continued work for the couple shifts from 74.5 percent to 72 percent. A test for the inclusion of wives' health insurance in the multinomial logit model confirms that this variable belongs in the model ( $\mathrm{p}=0.02)$. Including controls for pension benefits and controls for social security wealth in table 3 have little effect on the health insurance results (not reported in tables). We continue to find that wives' retiree health insurance enables couples to retire jointly. Since wives are on average four years younger than their husbands, wives' retiree health insurance plays an important role in enabling couples to retire jointly.

Couples where wives do not have employer provided health insurance are significantly less likely to have husbands retiring first relative to jointly retiring. Predicted probabilities based on model estimates show that 4.1 percent of couples with employer provided health insurance without retiree benefits retire jointly. In contrast, 5.9 percent of couples where the wife does not have employer provided health insurance retire jointly. A priori, it was unclear how employer provided health insurance would affect joint retirement relative to no employer provided health insurance. These results suggest that the lack of employer provided health insurance increases joint retirement since couples can choose to retire together unconstrained by health insurance considerations. However, it is also possible that wives who lack employer provided health insurance face a lower income loss from retiring or have "worse" jobs in nonpecuniary dimensions that encourage them to leave the labor force with their husbands. 
We conducted a number of specification checks that are not reported in the tables. First, we reran the models using measures of health insurance coverage from the current job only. These measures are available for 1996, 1998, 2000, and 2002. The health insurance measure used in the main models does not specify whether the health insurance is from a current or previous job. We found that the results for the health insurance measures were very similar to the results from the main model. In particular, for wives' retiree health insurance, the RRR for husband retires first versus joint retirement becomes $0.474(\mathrm{p}=0.014)$ for the specification reported in table 3. We do not report these results as our main results since we prefer a health insurance measure that is consistently defined over time. Second, we explored using a variable that measured whether or not retiree health insurance could cover the spouse; however, this variable was missing for most of the sample, and therefore could not be used in the analysis. ${ }^{22}$ Third, we included interactions between the health insurance variables and health measures available in the HRS, including number of medical conditions for the husband and wife, number of functional limitations, and self-reported health. We did not find any statistically significant interactions in our models. Fourth, we included interactions between the health insurance variables and age categories. In particular, we tested the hypothesis that couples who were over the age of 65 and eligible for Medicare would have a smaller retirement response to employer provided health insurance incentives than couples who were under the age of 65 and relied on employer provided health insurance as their sole source of health insurance coverage. While we found that the interactions between an indicator for over 65 and health insurance did have the correct sign, the interactions were statistically insignificant. Since only about 10 percent of our sample consisted of couples over 65 who were still working, we possibly lack the sample size to

\footnotetext{
${ }^{22}$ KFF-HRET(2005) reports that 98 percent of spouses of retirees are offered retiree health insurance, conditional on the employer offering retiree health insurance to the worker.
} 
estimate this interaction reliably. ${ }^{23}$ Fifth, we estimated models that included interactions between health insurance and the share of health insurance premiums borne by the employee for the years that this variable is available. We would expect the effect of retiree health insurance on retirement behavior to be larger if the share of premiums borne by the employee is smaller. While we found interaction estimates that were the right sign, these estimates were statistically insignificant.

\section{Effect of Other Factors on Joint Retirement}

Husbands' and wives' ages are jointly significant in the model in table 3 ( $\mathrm{p}<0.01$ for both tests). The age indicators for both husbands' and wives' age follow the expected pattern couples with older husbands are significantly more likely to jointly retire than to postpone retirement. Similarly, couples with older wives are more likely to jointly retire than to postpone retirement. The pattern for the age indicators for the comparisons between husbands retiring first and wives retiring first relative to joint retirement are more mixed and tend to be statistically insignificant. In addition, the interactions of husbands' and wives' age are not statistically significant $(\mathrm{p}=0.72) .{ }^{24} \mathrm{We}$ find a large and statistically significant effect of race on joint retirement. Non-white couples are substantially less likely to retire jointly than white couples. We also find some evidence that health affects joint retirement. Husbands' health, measured by self reported fair or poor health, increases the probability that couples will retire jointly relative to wives retiring first alone, and increases the probability that couples jointly retire relative to

$23 \mathrm{We}$ have also reestimated the models after dropping couples who are covered by public insurance before the age of 65. This restriction drops 120 couples from the data set and strengthens the results slightly. For example, for wife's retiree health insurance, the RRR for husband retires first versus a couple retiring jointly becomes 0.482 $(\mathrm{p}=0.042)$ in the specification reported in table 3 .

24 We combined adjacent age categories in cases where cell sizes were insufficient to estimate separate age indicators. 
neither retiring. Similarly, wives' poor health increases the probability that wives will retire jointly with husbands rather than husbands retiring alone first, and increases the probability that couples retire jointly relative to neither retiring. These results suggest that poor health inhibits work, and are consistent with the results found in the literature. These results also support the notion that care-giving may be a factor in determining joint retirement among couples with adverse health. Alternative measures of health such as medical conditions and functional limitations were imprecisely estimated when added to a model containing self reported health.

While we find no evidence that wages affect joint retirement, we do find some evidence that wives with longer tenure are significantly more likely to jointly retire with their husbands than to postpone retirement. This finding is consistent with the fact that wives with longer tenure are more likely to be eligible for pension benefits and therefore, are able to time their retirement to coincide with their husbands' retirement. The type of pension plan and pension wealth are jointly statistically significant in the joint retirement model $(\mathrm{p}<0.01) .{ }^{25} \mathrm{We}$ find that husbands with DB plans are more likely to jointly retire than to have their wives retire first alone, although this result is only significant at the 10 percent level. Wives' DB plans appear to reduce the probability of joint retirement relative to all other retirement options. Since wives are younger than their husbands, and are less likely to have been vested in their DB plans, their retirement timing is more likely to be based on pension considerations, thus reducing their ability to time their retirement with their husbands. DB pension wealth also has a significant effect on joint retirement. Husbands who have higher expected DB pension wealth gains from postponing retirement are more likely to have wives who retire first alone. Wives who have higher expected DB pension wealth gains from postponing retirement are relatively less likely to retire first alone compared to jointly retiring. Predictions based on model estimates show that the predicted

\footnotetext{
${ }^{25}$ Including interactions of the pension variables with wave indicators did not change the results.
} 
probability of wives retiring first alone falls from 8 percent to 4 percent when the DB pension wealth gains increases from the average in the sample to the $75^{\text {th }}$ percentile. Higher social security wealth increases couples' propensity to retire jointly relative to the husband retiring first alone; however, the gain in wealth from delaying retirement is statistically insignificant.

\section{Conclusion}

Availability of retiree health insurance increases couples' ability to time retirement together. However, this effect appears to exist only for wives' retiree health insurance, not for husbands' retiree health insurance. Wives' retiree health insurance more than doubles the propensity to retire jointly, suggesting that health insurance is an important consideration in coordinating retirement decisions among couples. Even though retiree health insurance has a substantial effect on joint retirement, its effect on overall employment patterns is modest, accounting for a 2 percentage point fall in employment from a base of 75 percent. Our results are broadly consistent with Blau and Gilleskie's (2003) findings of a stronger health insurance effect for women than for men. They also find relatively modest effects of health insurance on employment patterns of couples. Our findings suggest that even though health insurance does not have a large effect on overall employment patterns of couples, it does play an important role in joint retirement decisions. Couples appear to have "job lock" with respect to retirement if the wife, who is typically younger than the husband, does not have retiree health benefits.

Retiree health insurance from women's jobs may be a more important factor in joint retirement decisions than health insurance from men's jobs since women are typically younger than their husbands and need health insurance to cover themselves if they retire before 65 . While retiree health insurance from their husbands may potentially cover them, it is possible that 
premiums for dependent coverage are high enough to discourage retirees from covering their spouses on their policies.

Over the past decade, the provision of retiree health benefits has steadily declined -45 percent of workers were offered retiree coverage in 1992 compared to 30 percent of workers in 2002. Double-digit increases in the health insurance premiums coupled with the recent downturn in the economy has increased concerns that firms may increasingly choose to drop retiree health insurance from their benefit offerings. On the other hand, recent legislation adding a prescription drug benefit to Medicare may save employers enough in retiree health benefit costs to slow this trend. Over 60 percent of firms reported that they would save money and would retain drug coverage as a supplement to Medicare coverage after the prescription drug legislation is in effect. Even if firms maintain their retiree health benefits, an increase in cost sharing requirements and premiums appears inevitable (Kaiser/Hewitt, 2002). These trends suggest that couples will increasingly find it difficult to time their retirement together and yet maintain affordable health insurance coverage for both spouses. 


\section{References}

Agency for Healthcare Research and Quality. 2000 Medical Expenditure Panel Survey - Table Compendium. August 2003, Rockville, MD. http://www.meps.ahrq.gov/CompendiumTables/TC_TOC.HTM

An MY, Christensen BJ, Gupta ND. Retirement Incentives and Couples' Retirement Decisions. Working Paper 99-10, Centre for Labour Market and Social Research. December 1999.

Berger MC, Black DA, Scott FA, Chandra A. (1999). Health Insurance Coverage of the Unemployed: COBRA and the Potential Effects of Kassebaum-Kennedy. Journal of Policy Analysis and Management. 18(3):430-448.

Blau D, Gilleskie D. (2001). Retiree Health Insurance and the Labor Force Behavior of Older Men in the 1990's. Review of Economics and Statistics. 83(1):64-80.

Blau D, Gilleskie D. (2003). The Role of Retiree Health Insurance in the Employment Behavior of Older Men. NBER Working Paper 10100.

Blau DM. (1998). Labor Force Dynamics of Older Married Couples. Journal of Labor Economics. 16:595-629.

Blau DM, Gilleskie DB. (2003). Health Insurance and Retirement of Married Couples. Mimeograph, University of North Carolina at Chapel Hill, September 2003.

Campione WA. (1987). The Married Woman's Retirement Decision: A Methodological Comparison. Journal of Gerontology 42(4):381-386.

Coile C. (2003). Retirement Incentives and Couples' Retirement Decisions. NBER Working Paper 9496.

Currie JM, Madrian BC. (1999). Health, Health Insurance, and the Labor Market. In Handbook of Labor Economics, vol. 3, edited by Orley Ashenfelter and David Card (3309-3416). Amsterdam: Elsevier Science.

Flynn P. COBRA Qualifying Events and Elections, 1987-1991. Inquiry. (Summer 1994):215-220.

French E, Jones JB. (2003). The Effects of Health Insurance and Self-Insurance on Retirement Behavior. Unpublished paper, Federal Reserve Bank of Chicago.

Gustman A, Steinmeier T. (2001). What People Don't Know about their Pension and Social Security In William G. Gale, John B. Shoven and Mark J. Warshawsky, editors, Public Policies and Private Pensions, Washington D.C. Brookings Institution. 
Gustman A, Steinmeier T. (2002). Social Security, Pensions and Retirement Behavior within the Family. NBER Working Paper 8772.

Gustman AL, Steinmeier TL. (2000). Retirement in a Family Context: A Structural Model for Husbands and Wives. Journal of Labor Economics. 18:503-45.

Gustman AL, Tabatabai N. (2003). Imputations for Pension Related Variables in HRS 1992, HRS 1994, HRS 1996, HRS 1998, and HRS 2000. Researcher contribution to HRS website: www.hrsonline.isr.umich.edu.

Gruber J, Madrian BC. (1995). Health Insurance Availability and the Retirement Decision. American Economic Review. 85(4):938-948.

Gruber J, Madrian BC. (1996). Health Insurance and Early Retirement: Evidence from the Availability of Continuation Coverage. In Advances in the Economics of Aging, edited by David A. Wise, pp. 115-143. Chicago: University of Chicago Press.

Gruber J, Madrian BC. (2004). Health Insurance, Labor Supply, and Job Mobility: A Critical Review of the Literature. In Health Policy and the Uninsured, edited by Catherine G. McLaughlin, pp. 97-177. The Urban Institute Press, Washington D.C.

Headen, Jr., AE, Clark RL, Ghent LS. (1997). Effects of Retiree Health Insurance and Pension Coverage on the Retirement Timing of Older Workers: Sensitivity of Estimates. Unpublished paper, North Carolina State University.

Henretta JC, O'Rand A, Chan CG. (1993a). Gender Differences in Employment after Spouse's Retirement. Research on Aging. 15:148-169.

Henretta JC, O'Rand A, Chan, CG. ( 1993b). Joint Role Investments and Synchronization of Retirement: A sequential Approach to Couples' Retirement Timing. Social Forces. 71:981-1000.

Hurd MD. (1990). The Joint Retirement Decision of Husbands and Wives". In Issues in the Economics of Aging, edited by David A. Wise, Chicago: University of Chicago Press, 231-258.

Hurd M. (1990). The Joint Retirement Decisions of Husbands and Wives. In David A. Wise (ed.), Issues in the Economics of Aging, Chicago: University of Chicago Press, pp. 231-258.

Hutchens R. (1986). Delayed Payment Contracts and a Firm's Propensity to Hire Older Workers. Journal of Labor Economics. 4(4):439-457.

Johnson RW, Favreault MM. (2001). Retiring Together or Working Alone: The Impact of Spousal Employment and Disability on Retirement Decisions. CRR Working Paper 2001-01. Center of Retirement Research at Boston College.

Johnson RW, Davidoff AJ, Perese K. (1999). Health Insurance Costs and Early Retirement Decisions. Unpublished paper, The Urban Institute, Washington DC. 
Kaiser Family Foundation and Hewitt Associates. The Current State of Retiree Health Benefits. Findings from the Kaiser/Hewitt 2002 Retiree Health Survey. December 2002.

Kaiser Family Foundation and Hewitt Associates. Retiree Health Benefits Now and in the Future: Findings from the Kaiser/Hewitt 2003 Survey on Retiree Health Benefits. January 2004.

Karoly L, Rogowski J. (1994). The Effect of Access to Post-Retirement Health Insurance on the Decisions to Retire Early. Industrial and Labor Relations Review. 40:103-123.

Madrian BC. (1994). The Effect of Health Insurance on Retirement. Brookings Papers on Economic Activity. 1994(1):181-232.

Madrian BC, Beaulieu ND. (1998). Does Medicare Eligibility Affect Retirement? In Inquiries in the Economics of Aging, edited by David A. Wise (109-131). Chicago: University of Chicago Press.

Maestas N. Labor, Love and Leisure: Complementarity and the Timing of Retirement by Working Couples. Working Paper, Department of Economics, University of California, Berkeley, December 2001.

Maury D. (2001). Couples' Retirement Decisions: The Impact of Health and Race Differences. Mimeograph. Institut d'Etudes Politiques de Paris.

O'Rand A, Henretta JC, Krecker M. (1992). Family Pathways to Retirement. In Families and Retirement, edited by Szinovacz M., Ekerdt D., and Vinick B., Newbury Park, CA: Sage.

Pienta A. (1997). Older Couples: An Examination of Health and Retirement Within the Context of the Family. PSU Population Research Institute Working Paper Series 97-03.

Quinn J. (1997). The Role of Bridge Jobs in the Retirement Patterns of Older Americans in the1990s. In Retirement Prospects in a Defined Contribution World, D. Salisbury, ed., Employee Benefit Research Institute, pp. 25-39.

Rogowski J, Karoly LA. (2001). Health Insurance and Labor Force Transitions of Older Women Workers. RAND DRU-2728-DOL.

Rogowski J, Karoly L. (2000). Health Insurance and Retirement Behavior: Evidence from the HRS. Journal of Health Economics. 19(4):529-539.

Rust J, Phelan C. (1997). How Social Security and Medicare Affect Retirement Behavior in a World of Incomplete Markets. Econometrica. 65(4):781-831.

Scandlen G. Helping Laid-Off Workers Keep Insurance, Brief Analysis No. 373, Washington: National Center for Policy Analysis. Oct 4, 2001. 
StClair P, Bugliari D, Pantoja P, Ilchuk S, Lopez G, Haider S, Hurd M, Loughran D, Panis C, Reti M, Zissimopoulos J. SSA-HRS Data Documentation, PM-1172-SSA. June 2002. 
TABLE 1: MEANS IN THE HEALTH AND RETIREMENT SURVEY (1992-2002) Couple-year level data

\begin{tabular}{|c|c|c|}
\hline Variable & Mean & Standard Deviation \\
\hline \multicolumn{3}{|l|}{ Retirement Outcome } \\
\hline Couple retires jointly & $5.94 \%$ & \\
\hline Husband retires first & $13.34 \%$ & \\
\hline Wife retires first & $7.83 \%$ & \\
\hline Neither retires & $72.89 \%$ & \\
\hline \multicolumn{3}{|l|}{ Health Insurance } \\
\hline Husband has retiree $\mathrm{HI}$ & $49.31 \%$ & \\
\hline Husband has EPHI, no retiree $\mathrm{HI}$ & $20.59 \%$ & \\
\hline Husband has no EPHI & $30.10 \%$ & \\
\hline Wife has retiree $\mathrm{HI}$ & $26.02 \%$ & \\
\hline Wife has EPHI, no retiree $\mathrm{HI}$ & $18.10 \%$ & \\
\hline Wife has no EPHI & $55.88 \%$ & \\
\hline \multicolumn{3}{|l|}{ Demographic Characteristics } \\
\hline Husband Age & 56.77 & 4.17 \\
\hline Wife Age & 52.70 & 5.51 \\
\hline Nonwhite & $8.84 \%$ & \\
\hline Husband education: less than high school & $14.78 \%$ & \\
\hline Husband education: high school & $56.60 \%$ & \\
\hline Husband education: college & $28.62 \%$ & \\
\hline Wife education: less than high school & $10.52 \%$ & \\
\hline Wife education: high school & $68.51 \%$ & \\
\hline Wife education: college & $20.96 \%$ & \\
\hline Husband: Self reported health fair/poor & $10.17 \%$ & \\
\hline Wife: Self reported health fair/poor & $7.47 \%$ & \\
\hline \multicolumn{3}{|l|}{ Employment Characteristics } \\
\hline Husband wage & 17.83 & 16.99 \\
\hline Wife wage & 12.15 & 21.07 \\
\hline Husband tenure & 16.58 & 11.90 \\
\hline Wife tenure & 10.98 & 8.89 \\
\hline Husband has DB plan & $46.88 \%$ & \\
\hline Husband has DC plan & $37.88 \%$ & \\
\hline Wife has DB plan & $37.23 \%$ & \\
\hline Wife has DC plan & $32.96 \%$ & \\
\hline Husband DB pension wealth & 74573.40 & 165886.30 \\
\hline Husband DB pension gain & 6565.12 & 22014.14 \\
\hline Wife DB pension wealth & 28555.00 & 83756.30 \\
\hline Wife DB pension gain & 9206.12 & 21839.02 \\
\hline Husband DC pension wealth & 33613.22 & 133903.70 \\
\hline Wife DC pension wealth & 13726.32 & 175962.20 \\
\hline Social security wealth & 141255.30 & 44808.79 \\
\hline Social security gain & 38836.15 & 23344.18 \\
\hline Household IRA/Keogh wealth & 34859.45 & 75682.45 \\
\hline Other household wealth & 252493.60 & 613203.30 \\
\hline Days between interviews & 709.44 & 74.20 \\
\hline Number of Observations & 3370 & \\
\hline
\end{tabular}


TABLE 2: TABULATION OF HEALTH INSURANCE AND RETIREMENT OUTCOMES

\begin{tabular}{lrrr}
\hline \multicolumn{4}{c}{ Husband's health insurance } \\
\hline & No EPHI & EPHI, no retiree HI & Retiree HI \\
Couple retires jointly & $4.84 \%$ & $6.08 \%$ & $6.55 \%$ \\
Husband retires first & $13.68 \%$ & $9.94 \%$ & $14.55 \%$ \\
Wife retires first & $8.15 \%$ & $8.29 \%$ & $7.43 \%$ \\
Neither retires & $73.32 \%$ & $75.68 \%$ & $71.46 \%$ \\
\hline
\end{tabular}

\begin{tabular}{lrrr}
\hline \multicolumn{4}{c}{ Wife's health insurance } \\
\hline & No EPHI & EPHI, no retiree HI & Retiree HI \\
Couple retires jointly & $6.04 \%$ & $4.04 \%$ & $7.05 \%$ \\
Husband retires first & $12.20 \%$ & $15.87 \%$ & $14.03 \%$ \\
Wife retires first & $8.80 \%$ & $5.96 \%$ & $7.02 \%$ \\
Neither retires & $72.96 \%$ & $74.12 \%$ & $71.90 \%$ \\
\hline
\end{tabular}


TABLE 3: ESTIMATES FROM MULTINOMIAL LOGIT MODEL OF JOINT RETIREMENT

\begin{tabular}{|c|c|c|c|c|c|c|}
\hline & \multicolumn{2}{|c|}{$\begin{array}{l}\text { Husband retires first } \\
\text { /Jointly retire }\end{array}$} & \multirow{2}{*}{$\begin{array}{c}\text { Wife retires first } \\
\text { /Jointly retire } \\
\text { RRR }\end{array}$} & \multirow[b]{2}{*}{ SE } & \multirow{2}{*}{$\begin{array}{c}\text { Neither retire } \\
\text { /Jointly retire } \\
\text { RRR }\end{array}$} & \multirow[b]{2}{*}{ SE } \\
\hline & RRR & SE & & & & \\
\hline \multicolumn{7}{|l|}{ Health Insurance } \\
\hline Husband has retiree $\mathrm{HI}$ & 1.387 & 0.366 & 0.820 & 0.233 & 0.847 & 0.194 \\
\hline Husband has no EPHI & 1.232 & 0.399 & 1.187 & 0.398 & 1.205 & 0.341 \\
\hline Wife has retiree $\mathrm{HI}$ & 0.466 & 0.141 * & 0.577 & 0.205 & 0.491 & $0.135 * *$ \\
\hline Wife has no EPHI & 0.528 & 0.159 * & 1.079 & 0.373 & 0.654 & 0.183 \\
\hline \multicolumn{7}{|l|}{ Demographic Variables } \\
\hline Husband Age: 54-55 & 0.695 & 0.386 & 0.519 & 0.302 & 0.364 & 0.180 * \\
\hline Husband Age: 56-59 & 0.937 & 0.506 & 0.601 & 0.347 & 0.402 & 0.197 \\
\hline Husband Age: 60-62 & 0.876 & 0.501 & 0.273 & 0.190 & 0.100 & $0.053^{* *}$ \\
\hline Husband Age: 63 or older & 2.262 & 2.708 & 0.119 & 0.156 & 0.133 & 0.150 \\
\hline Wife Age: $54-55$ & 0.888 & 1.188 & 6.835 & 9.167 & 1.736 & 2.220 \\
\hline Wife Age: 56-59 & 0.046 & 0.059 * & 0.474 & 0.475 & 0.274 & 0.216 \\
\hline Wife Age: 60 or older & 0.092 & $0.083 * *$ & 1.851 & 1.186 & 0.219 & 0.123 ** \\
\hline Husband Age 54-55 \& Wife Age 54-55 & 1.739 & 2.786 & 0.291 & 0.475 & 0.933 & 1.405 \\
\hline Husband Age 54-55 \& Wife Age 56-59 & 8.660 & 13.374 & 1.191 & 1.612 & 1.210 & 1.311 \\
\hline Husband Age 56-59 \& Wife Age 54-55 & 1.109 & 1.590 & 0.140 & 0.205 & 0.419 & 0.573 \\
\hline Husband Age 56-59 \& Wife Age 56-59 & 8.449 & 11.309 & 2.352 & 2.590 & 1.361 & 1.190 \\
\hline Husband Age 60-62 \& Wife Age 54-55 & 1.145 & 1.699 & 0.183 & 0.294 & 0.607 & 0.869 \\
\hline Husband Age 60-62 \& Wife Age 56-59 & 17.664 & 23.743 * & 2.787 & 3.268 & 3.420 & 3.045 \\
\hline Husband Age 60-62 \& Wife Age 60+ & 2.167 & 2.197 & 0.812 & 0.702 & 1.425 & 1.001 \\
\hline Husband Age 63+ \& Wife Age 56-59 & 11.139 & 18.167 & 4.910 & 7.698 & 1.620 & 2.051 \\
\hline Husband Age 63+ \& Wife Age 60+ & 0.842 & 1.140 & 0.692 & 0.908 & 0.507 & 0.566 \\
\hline Nonwhite & 3.325 & $1.271 * *$ & 4.151 & $1.677^{\star *}$ & 2.718 & 0.979 ** \\
\hline Husband education: high school & 1.090 & 0.304 & 1.408 & 0.433 & 1.542 & 0.384 \\
\hline Husband education: college & 0.934 & 0.328 & 1.615 & 0.622 & 1.725 & 0.544 \\
\hline Wife education: high school & 0.716 & 0.236 & 0.663 & 0.249 & 0.908 & 0.280 \\
\hline Wife education: college & 0.957 & 0.421 & 0.918 & 0.448 & 1.299 & 0.521 \\
\hline Husband: Fair/Poor health & 0.754 & 0.215 & 0.509 & 0.175 * & 0.560 & 0.142 * \\
\hline Wife: Fair/Poor health & 0.571 & 0.185 & 1.453 & 0.470 & 0.428 & $0.121^{* *}$ \\
\hline
\end{tabular}


TABLE 3: ESTIMATES FROM MULTINOMIAL LOGIT MODEL OF JOINT RETIREMENT (CONTINUED)

\begin{tabular}{|c|c|c|c|c|c|c|}
\hline & $\begin{array}{c}\text { Husband re } \\
\text { /Jointly reti } \\
\text { RRR }\end{array}$ & $\begin{array}{r}\text { first } \\
\text { SE }\end{array}$ & $\begin{array}{c}\text { Wife retires } \\
\text { /Jointly retire } \\
\text { RRR }\end{array}$ & SE & $\begin{array}{c}\text { Neither retire } \\
\text { /Jointly retire } \\
\text { RRR }\end{array}$ & SE \\
\hline \multicolumn{7}{|l|}{ Employment Variables } \\
\hline Husband log wage & 0.864 & 0.150 & 1.130 & 0.228 & 0.858 & 0.144 \\
\hline Wife log wage & 1.127 & 0.222 & 0.854 & 0.168 & 0.994 & 0.172 \\
\hline Husband tenure & 0.992 & 0.008 & 0.988 & 0.010 & 0.988 & 0.008 \\
\hline Wife tenure & 0.996 & 0.011 & 0.994 & 0.012 & 0.969 & 0.010 * \\
\hline Husband has DB plan & 0.448 & 0.287 & 0.336 & 0.215 & 0.491 & 0.252 \\
\hline Husband has DC plan & 0.929 & 0.997 & 2.697 & 2.883 & 1.753 & 1.671 \\
\hline Wife has DB plan & 2.531 & 1.238 & 2.480 & 1.340 & 2.101 & 0.938 \\
\hline Wife has DC plan & 0.766 & 0.596 & 0.317 & 0.278 & 1.100 & 0.757 \\
\hline Husband DB pension wealth (in logs) & 1.021 & 0.052 & 1.003 & 0.050 & 0.999 & 0.040 \\
\hline Husband DB pension gain (in logs) & 1.031 & 0.028 & 1.103 & $0.033^{* *}$ & 1.032 & 0.024 \\
\hline Wife DB pension wealth (in logs) & 0.955 & 0.039 & 1.011 & 0.047 & 0.977 & 0.036 \\
\hline Wife DB pension gain (in logs) & 0.950 & 0.031 & 0.872 & $0.031^{* *}$ & 0.959 & 0.028 \\
\hline Husband DC pension wealth (in logs) & 0.954 & 0.098 & 0.898 & 0.091 & 0.924 & 0.084 \\
\hline Wife DC pension wealth (in logs) & 1.031 & 0.086 & 1.129 & 0.105 & 1.028 & 0.075 \\
\hline Social security wealth (in logs) & 0.877 & 0.047 * & 0.958 & 0.055 & 0.948 & 0.046 \\
\hline Social security gain (in logs) & 1.020 & 0.061 & 0.971 & 0.063 & 0.977 & 0.053 \\
\hline \multicolumn{7}{|l|}{ Other Variables } \\
\hline Household IRA wealth (in logs) & 1.013 & 0.021 & 1.015 & 0.024 & 1.001 & 0.018 \\
\hline Other household wealth (in logs) & 0.954 & 0.070 & 0.926 & 0.073 & 0.898 & 0.061 \\
\hline Interview length (in logs) & 0.499 & 0.511 & 0.588 & 0.634 & 0.262 & 0.237 \\
\hline Wave 2 & 1.131 & 0.309 & 0.914 & 0.271 & 0.890 & 0.221 \\
\hline Wave 3 & 0.594 & 0.184 & 0.544 & 0.185 & 0.674 & 0.182 \\
\hline Wave 4 & 1.007 & 0.365 & 0.557 & 0.228 & 0.964 & 0.318 \\
\hline Wave 5 & 1.253 & 0.477 & 0.687 & 0.295 & 1.054 & 0.359 \\
\hline
\end{tabular}

Note 1: RRR denotes relative risk ratios. SE denotes standard errors

Note 2: * denotes significance at the $5 \%$ level; ${ }^{* *}$ denotes significance at the $1 \%$ level

Note 3: Indicators for imputed/missing pension and wage variables are included in the model but not reported 